D.V. Scums ${ }^{1}$, S.V. Nikanenka ${ }^{2}$, A.V. Danilchyk ${ }^{2}$, V.A. Zhdanovskii ${ }^{2}$, A.V. Kreidzich ${ }^{2}$, E.V. Lutsenko ${ }^{2}$

${ }^{1}$ Belorussian State Institute of Metrology - BelGIM, Minsk, Belarus

${ }^{2}$ B. I. Stepanov Institute of Physics National Academy of Sciences of Belarus, Minsk, Belarus

\title{
NEW TYPE OF REFERENCE LIGHT SOURCE FOR CALIBRATION OF LUXMETERS AND PHOTOMETERS
}

\begin{abstract}
In BelGIM was created the setup for luxmeters and photometers calibration on basis of new type of reference light source. Light source was created on the base of the hemisphere, quartz-halogen lamps and LEDs. Created source provides (at the distance of $500 \mathrm{~mm}$ ) average value of irradiance within the light spot $(65 \mathrm{~mm})$ at least $4000 \mathrm{~lx}$ with illumination by LEDs and $3000 \mathrm{~lx}$ with illumination by lamps. Uniform illumination within the light spot does not exceed $1 \%$. The uniform distribution of the correlated color temperature of the radiation within the spot is better than $\pm 10 \mathrm{~K}$.
\end{abstract}

Key Words: photometry, calibration, source, LED, illuminance.

\section{Introduction}

The appearance on the market in the last 20 years of high precision photometers, photometric head $(\mathrm{PH})$ and luxmeters allowed use them as working standards instead standard lamps. The photometric calibration of the units are carried out on a photometric bench. As a radiation source is used the standard lamps that correspond to the source CIE A with correlated color temperature $T_{\mathrm{cp}}=2856 \mathrm{~K}$. Typically, the measurements is performed at illuminance levels from 100 to $200 \mathrm{~lx}$ at the distance between the standard lamp and detector about $2 \mathrm{~m}$. However, for testing the linearity of photometers (PH or luxmeters) it is necessary to carry out the measurement in the range of 0.1 to $1000 \mathrm{~lx}$. At the same time it is difficult to make possible a high level of illuminance for measurements, which is important for instruments used for the measurement of high power radiation sources used for lighting of roads, warehouses, sports facilities, etc. This caused by, firstly: according to calibration scheme on GOST 8.023 it is necessary to transfer the unit of illuminance creating by the standard lamp with a nominal value of luminous intensity $35 \mathrm{~cd}$, $100 \mathrm{~cd}$ and $500 \mathrm{~cd}$, which is not enough to provide the level 1000 lx. A commercially available standard lamp with a nominal luminous intensity of $500 \mathrm{~cd}$ do not have stable optical characteristics due to the influence of high temperature heating of the bulb and base of the lamp, and therefore requires a special cooling system. Second, if to decrease a distance at calibration, it is possible to increase the illuminance level. But this is no effectively, since at distances of less than $1.5 \mathrm{~m}$ the error is exponentially increased due to the influence of the geometric factor.

In the leading national metrology centers the special sources was created to provide the illuminance lev- els more than 1000 1x. For example, in the PTB (Germany) is a powerful source on base of $20 \mathrm{~kW}$ lamp. The main disadvantage of this source is its high cost, complicated water-cooling system and the stability of power supply.

So, at present it is important to create of a powerful light source for providing testing and calibration of luxmeters and photometers.

\section{Design of reference light source}

One of the main task carried out in the creation of the facility was the build-up of the combined light source, which is based on the radiator with the spectral distribution of radiation close to the standard CIE A source and LED emitter.

The value of the illuminance is strictly standardized by the number of technical regulations and should be controlled carefully. However, all types of luxmeters (photometers) used in Belarus are calibrated or tested against the standard source CIE A, which relative spectral distribution of the radiation power is quite different from the spectral distribution of the LED radiation. Theoretical studies show that by this reason the measurement error of illumination should significantly rise [1 - 3]. In our previous research was defined that in the case of changing from CIE A source to the LEDs illuminance measurement uncertainty is increased in some cases [4-6]. In this case the relative uncertainty of the illuminance measurement by the luxmeters is not higher than $4 \%$, the relative uncertainty of the illuminance measurement decelerated by the producer is $6-10 \%$ according to the type of luxmeter [4-6].

This means that the massive renewal of the exploited in the country luxmeters is not necessary. However, since the measurement error is slightly higher, 
than the manufacturer represented error, the measurement error separately for incandescent lamps and LED have to be specified in the State register of measuring devices approved for use in the field of legal metrology.

The nowadays used in BelGIM facility UPF for calibration of luxmeters are obsolete; the new automated facility for calibration of luxmeters/photometers UPF-2 was created. Facility based on the light source, which includes both incandesced lamps and LEDs.

The LED is a point light source. Therefore, in the case of using of set of individual LEDs it is required to perform the averaging of the luminous flux in order to achieve the uniformity of the produced illuminance. On the practice an integrating sphere (IS) is usually used as a reference diffuse light source for testing of luxmeters, photometers and photometrical detectors. The IS is a truncated Ulbricht sphere with an inner unselective matte white painted surface covered by $\mathrm{BaSO}_{4}$, Spectralon or Spectraflex and with light sources outside mounted. Such IS are used for the measurement of the luminous flux. At last time a lot of theoretical studies were done in order to develop the method of measurements of the luminous flux with the hemisphere. The hemisphere method has following advantages [7]: less occupied space; less area of the degrading cover; there is no need to use baffles; the control of the reflective inner surface is easier. The comparison of the measurement data of luminous flux from the different lamps obtained with photometric hemisphere and IS demonstrates the close results [7]. Obviously, these advantages take place when photometric hemisphere is used as a diffuse light source. Considering that the uniformity of the illuminance distribution within the spot should not exceed $2.5 \%$, such constructive solution is suitable for this task.

The structure chart of created hemisphere light source (HLS), which consists of a hemisphere and a reflector is demonstrated on the Fig. 1. The inner surface of the hemisphere is coated with barium sulfate. The ratio of the hemisphere diameter to the diameter of the output aperture is $5 / 1$. The illumination block of the HLS has lamps and LEDs-sources. LEDs-sources consist of the 16-th LEDs: Lumileds Luxeon S1000 LXS8PW27 (8 pieces) and Luxeon S1000 LXS9-PW30 (8 pieces). The 8 Lumileds Luxeon S1000 LXS8-PW27 have the correlated color temperature between $2725 \mathrm{~K}$ and $2795 \mathrm{~K}$, the 8 Luxeon S1000 LXS9-PW30 have the correlated color temperature between 3045 and to $3129 \mathrm{~K}$. These correlated color temperature were so chosen because mean value the commercially produce LED sources is about $2900 \mathrm{~K}$. LEDs are mounted in inner surface of the hemisphere, they are located equidistance around the output aperture and symmetrical to the optical axis of the HLS on the service board. Coolers 3 and 14 Fischer Elektronik LA 9/200 230V mounted outside of the hemisphere provide the necessary cooling of LEDs. A special protective ring serves to shield the LED elements and contact wires. The ring has the holes for LEDs lenses.

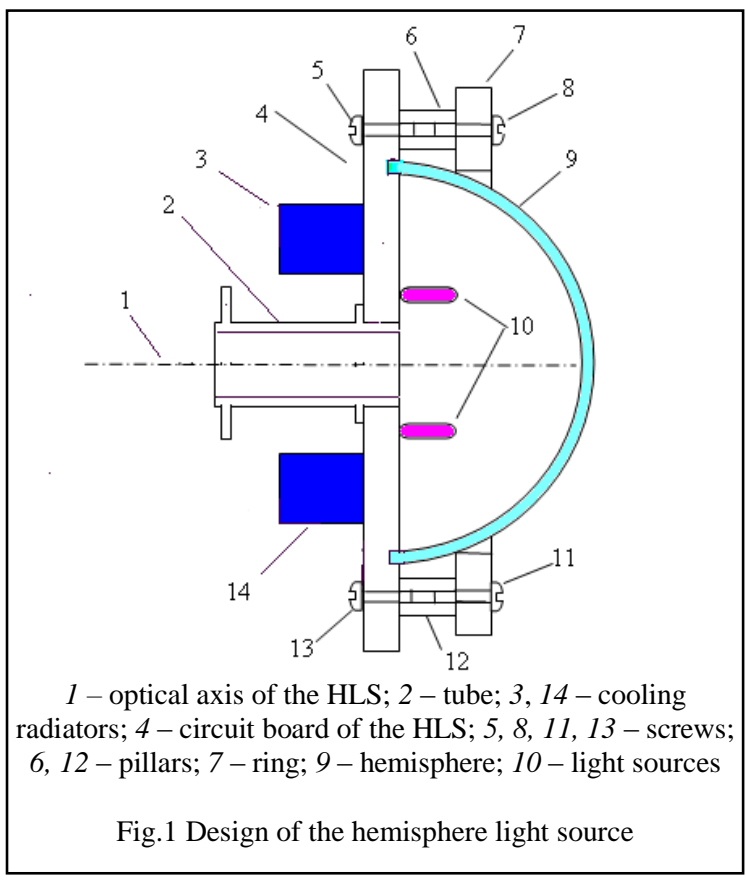

The lamp unit of the HLS illumination block is presented by 4 small quartz-halogen lamps (Osram HLX 6464, $150 \mathrm{~W}$ ). Lamps were installed so that they bulbs were inside the HLS, and were arranged symmetrically to the optical axis of the HLS. The lamp cooling is carried out with the coolers and additionally the outside installed fan. The Aghilent 6576 and BK Precision X195 supplies of the quartz-halogen lamps and LEDs respectively. The current and voltage control of the quartz-halogen lamps and LEDs was provided by two multimeters Aghilent 34410.

\section{Optical characteristics of hemisphere light source}

In the results of the study of the optical characteristics of the HLS was established that the source provides illuminance of $4 \mathrm{klx}$ at the correlated color temperature of $2863 \mathrm{~K}$ at the distance of $0.5 \mathrm{~m}$. According to test results HLS showed high stability and reproducibility. A drift of the illuminance produced per 3 hours was not higher than $\pm 0.25 \%$. The non-uniformity of the light spot diameter of $65 \mathrm{~mm}$ at the distance of $0.5 \mathrm{~m}$ was not more than $1.6 \%$.

Figure 2 shows the results of measurements nonuniformity on luminance of the HLS.

\section{Conclusions}

A combined light source based on small quartzhalogen lamps and the white LED for calibration luxmeters are developed. Created source provides (at the dis- 
tance of $500 \mathrm{~mm}$ ) average value of illuminance within the light spot $(95 \mathrm{~mm})$ is at least $4000 \mathrm{~lx}$ with illumination by LEDs and $30001 \mathrm{x}$ with illumination by lamps. Uniform illumination within the light spot does not exceed $1 \%$. The uniform distribution of the correlated color temperature of the radiation within the spot is better than $\pm 10 \mathrm{~K}$.

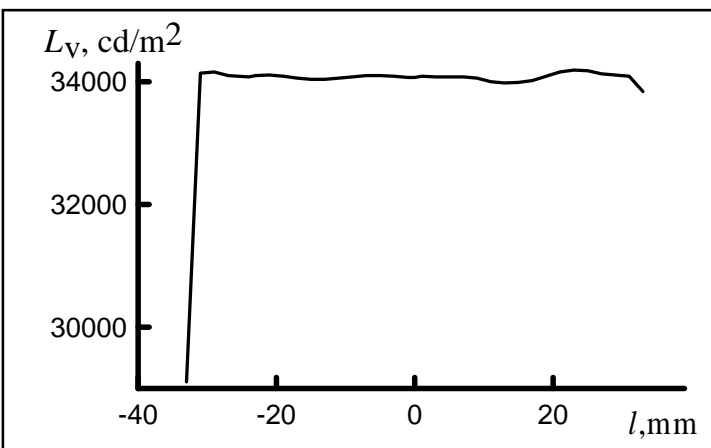

Fig.2 Luminance distribution of the hemisphere light source

\section{References}

[1] Gombos, K. Solid State Lighting, a Challenge for Photometry and Colorimetry / K. Gombos, J. Schanda // Light \& Engineering. - 2009. - Vol.17. -№ 2. - P. 17 25.

[2] Никифоров, С. Трудная задача измерения параметров света от светодиодов. Вопросы фотометрии и радиометрии. / С. Никифоров //Полупроводниковая светотехника, - 2010. - № 1. C. $36-40$.

[3] Никоненко, С.В. Влияние спектральной чувствительности фотометров на измерение силы света белых светодиодов / С.В. Никоненко, Е.В. Луценко, О.Б. Тарасова // Метрологія та вимірювальна техніка (МЕТРОЛОГІЯ-2010): наукові праці VII Міжнар. науко-во-техніч. конф. Харьків, 12-14 жовтня 2010 р.: в 2 т. / ННЦ «Інститут метрологіi». - Харьків, 2010. - Т. 2. - С. 19 - 22.

[4] Скумс Д.В. Измерение освещённости, создаваемой светодиодами и источниками на их основе/Д.В. Скумс, О.Б. Тарасова, А.А. Липлянин, С.В. Никоненко/ Метрология и измерительная техника (МЕТРОЛОГИЯ-2012): VIII Междунар. науч.-техн. конф., Харьков, 9-11 окт. 2012 г. / ННЦ «Институт метрологии». [Электронный ресурс]. - Электрон. текстовые дан. и прогр. (45,7 Мб). - Харьков, 2012. 1 электрон. опт. диск (CD-ROM). C. 355 - 357.

[5] Скумс Д.В. Источники погрешностей освещенности создаваемой светодиодами. / Д.В. Скумс [и др.]// Приборостроение - 2012 : Материалы 5-й Междунар. науч.-техн. конф., Минск, 21-23 ноября 2012 г.- Минск: БНТУ, 2012. - С. 219 - 220.

[6] Скумс Д.В. Погрешности измерения освещенности создаваемой светодиодами /Д.В. Скумс, О.Б. Тарасова, А.А. Липлянин, С.В. Никоненко/ Фотометрия и ее метрологическое обеспечение: тезисы докладов XIX научно-технической конф., Москва, 16-19 апреля 2013 г. - М.: Логос. 2013. - С. $38-40$.
[7] Ohkubo, K. Integrating sphere theory for measuring optical radiation / K. Ohkubo // J. Light Vis. \& Env. 2010. - Vol.32. - P. $57-68$ 